\title{
HUMAN RESOURCES AS A FACTOR OF COMPETITIVENESS AND QUALITY IN THE HOSPITALITY INDUSTRY
}

\author{
Iva Bulatović, \\ Silvana Đurašević, \\ Ana Stranjančević
}

\author{
Mediterranean University, \\ Montenegro Tourism School, \\ Podgorica, Montenegro
}

\begin{abstract}
:
Large and successful companies are aware of the importance of the human factor. Unfortunately, there are those much smaller ones and not so successful, where profit is the only vision, mission and goal. Many did not think and still do not think about the ways that will provide them benefits, and misuse of one's knowledge and skills has never been valued, nor it will be. The loss of employee loyalty is the result of non-compliance with the employee individuality, their wishes and needs, which is particularly prominent in the services sector. This paper deals with human resources and their function in the hotel industry of Montenegro. The aim of the paper is to highlight the importance of human resources for tourism development of Montenegro, the importance of investing in this type of capital in order to ensure quality and destination competitiveness. The model of individual performance was used herein, which was adapted and amended with the aim to be used in the analysis of effectiveness and competitiveness of hotel companies.
\end{abstract}

Keywords:

human resources, destination competitiveness, tourism, hospitality.

\section{INTRODUCTION}

It is generally well-known that a hotel product is composed of services, and that its features must not be forgotten whatsoever. As a reminder, we will explain the characteristics of services, and accordingly, hotel products.

Services, unlike products cannot be seen, touched, tried, smelled, or heard before purchasing. A clerk at the sales department in a hotel cannot take a room with him as a response to a request for booking. Services are intangible, which represents a significant barrier to their use, because before consumption and purchase, the sale must be based on the experience of consuming which is well presented. Services can be produced and consumed at the same time and in the presence of "producers" and consumers. Indivisibility of services also means that the constituent part of a hotel product, that is, service, is its very consumer, that is, travel consumer. Travel consumer significantly affects production of adequate services, by means of selecting different sets of services during their stay in the hotel, or meals and drinks at the restaurant, ways of serving etc. Services cannot be stored. Unfilled hotel capacity cannot be made good or excellent by occupancy in the next period. Demand and supply compatibility is crucial for the effective services utilisation of service capacities. Service variability 
is conditioned by the fact that the subjective factor, that is, human factor, is crucial for the quality of implementation. The service is unique, like a role of an actor on stage, it can be at a high level of quality that satisfies a user, but all the elements in the process of provision and consumption cannot happen again. Simultaneity of consumption and provision of services through interaction of both sides creates a unique atmosphere (Kotler et al., 2014).

It is these particular qualities of services, and therefore the hotel product, that indicate the importance of human factor in the process of providing services and, of course, when selling hotel products. The theory and practice have shown that the following paragraphs are correct:

- Hotel industry resulted in order to fulfill desires, demands and needs of tourists/guests.

- Guest pays both to you and me.

- The measure of quality of a hotel product is the number of satisfied guests.

- The so-called. "Buzz marketing" - marketing "word of mouth" is still the most effective (Holjevac, 1998).

Now the question arises: What/whom does the satisfaction of guests depend on, and therefore their rearrival, arrival of their friends, good advertising, good reputation of the hotel, increase in profit? The level of competitiveness of a hotel and quality of hotel product?

It mostly depends on the hotel staff. Especially nowadays, when competition is getting stronger each day, when luxuriously equipped hotel facilities are not a rarity, man plays the major role and holds all "strings" in their hands, since a guest in the $21^{\text {st }}$ century is sophisticated and requires the "right things", asks for EXPERIENCE! And this is one of the leading trends cited by the UNWTO - Change from service to experience! Memorable moments cannot be provided by gilded dining accessories and silk sheets, a guest can have it in another hotel as well, what a guest remembers is the staff, i.e. their attitude, their behavior, kindness or unkindness.

It should be noted that the largest cost for a hotel company is when a guest notices and charges a mistake. However, many mistakes (technical deficiencies or defects caused by accident) may be replaced by a warm smile and an apology by the providers of services, gift or discount, in our language a fixed phrase "on the house", while, on the other side, high-category hotels cannot replace unkind and discourteous staff. The guest does not forgive or forget such mistakes. We conclude that the psycho-physical characteristics of service providers can significantly cause consumer satisfaction or dissat- isfaction, regardless of the technical, organizational and technological segments of service quality (Kotler, Bowen, Makens, 2014). Thus, the focus of quality is transferred to service performers, catering staff and hotel management. It is important to remember that the quality is determined by labor standards (regulations that determine the quality elements of staff in a hotel: knowledge, skills, experience, appearance, behavior...) (Holjevac, 1998). This means that service providers must have certain characteristics: education (by degree and profile), quality of work, general culture, business culture, natural or learned kindness, stable personality, courtesy, confidentiality, integrity, communication, patience, personal charm, relatively good physical appearance (Curuvija, 2007).

\section{LITERATURE REVIEW}

Productivity plays a key role in determining the living standard of each country i.e. the standard of living of a country depends on its ability to produce goods and services. Productivity can be defined as the amount of goods and services that an employee produces for each hour of work (i.e. the amount one produces within a given unit of time) and it is directly determined by the factors of production such as physical capital, natural resources, technological knowledge and human capital. For the purposes of this paper, we will specifically deal with human resources and human capital. One can find different names for the concept of human capital in the literature: social capital (Payne et al., 2011; McFadyen \& Cannella, 2004), human capital (Becker, 1993), intellectual capital (Stewart, 1997). Human capital can be explained as an economic term for knowledge and skills that workers acquire through education, training and experience (Mankju, 2006). Human resources and human capital are increasingly gaining in importance in the sphere of business and beyond. Čačić (2010) points out that the material and human capital make the property of a company. This is particularly evident in the service sector in which the man assumes the most important role.

It is well-known that in all areas of social and economic development, human resources represent the basis of successful business, apart from having a significant role. According to Bakić (2002), employee education, development and training are the vital components of maintaining the competitiveness in service sector. This implies that investing in training and additional education of staff in service sector is necessary, especially in hotel industry.

Marchante and Ortega (2012) state that a mismatch between education levels required for a job and education levels of employees can explain differences in the 
hotel staff productivity. Much more efficient are those employees who are suitably educated, unlike those who are not, while at the same time; overeducated employees are more efficient than those undereducated (Marchante \& Ortega, 2012). The appropriate structure of employee education level according to their job requirements, definitely leads to higher level of labor productivity and the overall business success of hotel industry organizations.

Apart from the appropriate level of education, the productivity and competitiveness of hotel companies largely depend on special skills of their employees. Sheldon and Gee (1987) identified the most important skills so that hotel staff could be provided with certain trainings. Employees and employers agreed on the statement that human relations, communications, and courtesy skills are of the greatest importance. However, there was no agreement on the skills dealing with salesmanship, operations and computer skills, while at the same time the lowest ranked were knowledge of local people and their culture (Sheldon \& Gee, 1987). Since mentioned knowledge and skills are the basis for successful development in contemporary business environment, we can say that the knowledge of foreign languages and information and communication technology is only the precondition for engagement in the hotel industry.

We can state with certainty that human resources as the bearers of human capital are the source of competitiveness in the market. Thus, Podolny \& Baron (1997) argue that the concept of social capital is an important factor that can affect the competitive advantage and performance of a company. Furthermore, the role and importance of human resources in business environment have influenced the reforms of traditional organizations, so nowadays we may more frequently come across the so-called "knowledge organization". The learning organization concept is based on the constant learning of individuals, employees, so the organization itself learns and makes progress. This is a two-way process. Individuals and their knowledge and skills can improve the productivity and competitiveness of an organization, but also an organization can do something so that individuals improve their individual skills and acquire new knowledge. The learning organization expresses its ability to produce and acquire new knowledge, new concepts, and successfully adapt them to the business environment and its intentions. Today, in times of strong general uncertainty, it is very important to create a flexible organization that can adapt to new changes, but this is only feasible if it has quality resources, and rich human capital. The learning organization encourages teamwork, communication between different business functions, and willingness to communicate with various stakeholders with the aim to improve performance.

The evolution of the role of employees is a consequence of business model and organization of business processes (Mankju, 2006, p. 477). In the $21^{\text {st }}$ century, human capital has become the greatest wealth of an organization.

\section{METHODOLOGY}

For the purpose of this article, we have conducted the study based on the available secondary data including the applicable statistical data, certain analysis and reports done by relevant organizations, and vital national strategies dealing with human resources in the tourism field. In order to carry out the research, we used several scientific methods: methods of analysis, deduction and induction. Based on Literature review, we made the main conclusions that enable us to identify the most important models for analyzing the performances of hotel enterprises.

For the purpose of this article, the Model of individual performance was used. Based on our analysis and the main conclusions, we have adapted and amended this model. We created such a model for a detailed analysis of hotel companies, especially those related to their effectiveness and competitiveness.

It has been said that human resources and their particular character come to the fore in the service industry, such as hotel industry. To stress the importance and the role of human resources in the hotel industry and their impact on the quality and competitiveness of a hotel product, we shall present the Model of individual performance.

Business satisfaction, employee loyalty to the company, productivity, quality and service depend on an individual, his/her knowledge and skills, motivation and support one receives from the company, and nature of the job.

These variables are used to measure the effectiveness of operations in an organization. Additionally, we argue that this model can be useful in measuring the competitiveness of an organization. In fact, quality is a measure of competitiveness, but we said that the quality largely, if not entirely, depends on the human factor. The present model can be applied in the hotel industry of any country, including Montenegro. The category "Individual" as a subjective labor factor is essential to the effectiveness and efficiency of the entire work process in a hotel, while category "Work" appears as an objectively necessary supporting labor factor. From the aspect of possibility 


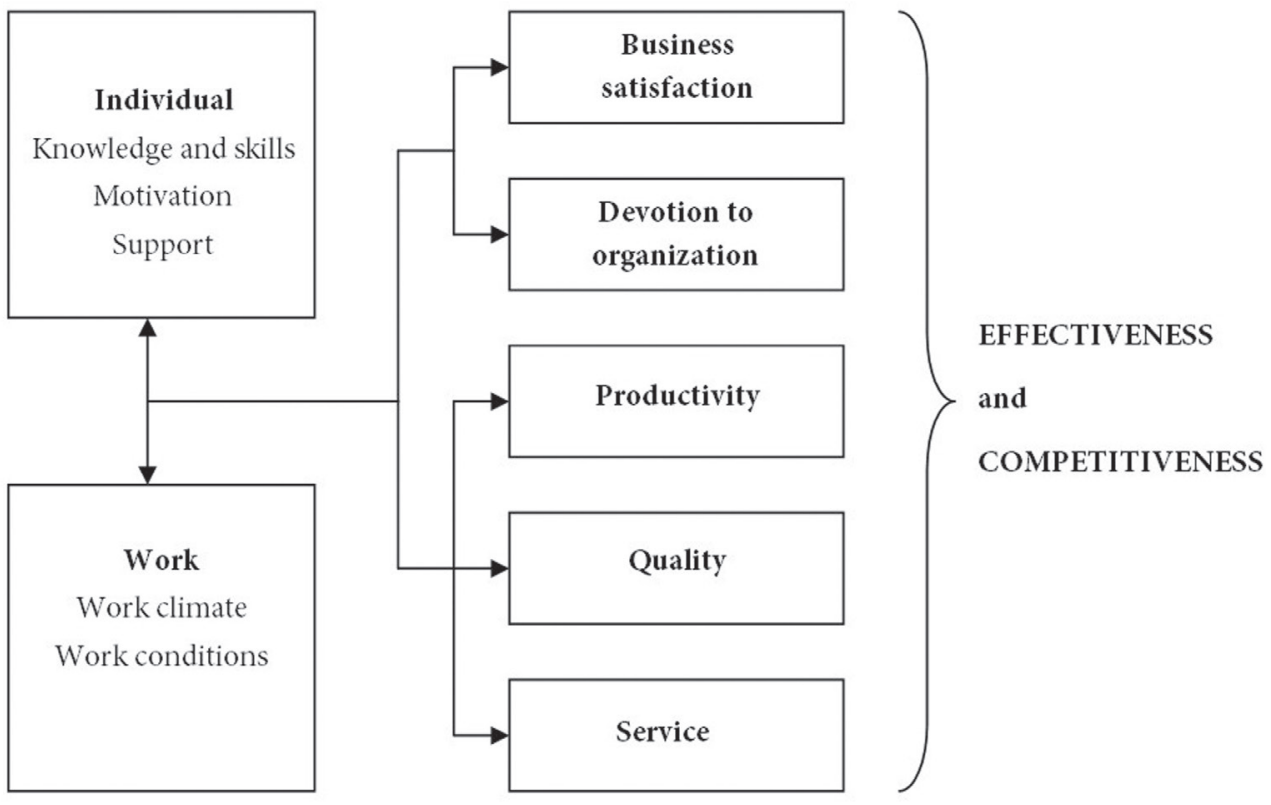

Chart 1. Model of individual/organizational performance Source: Adapted according to Mathis, Jacson (2008, p. 81)

of action on certain labor factors to increase business efficiency and competitiveness, the subjective labor factors can be influenced more than the objective ones.

\section{Category - Individual productivity}

A man is the trump, a major competitive advantage in hotel industry, and therefore deserves our dedication and analysis of factors affecting his productivity. Namely, the productivity of an individual depends on three categories:

- Knowledge and skills

- Motivation and effort

- Support they receive from the organization

In the next chapter, we will give a brief analysis of the individual productivity of human resources in the hotel industry of Montenegro.

\section{RESULTS AND DISCUSSION}

The tourism development strategy in Montenegro by 2020 (DEG, GTZ, MTZZS, 2008) allocates a decisive role in tourism development to human capital. It particularly highlights the importance of staff in the hotel and restaurant industry, travel agencies and numerous organizations in the sphere of services at the local, regional level, and at the country level as a whole. Knowledge and skills required of employees in the hotel industry vary from sector to sector, the functions performed within a single sector, i.e. the level of management in which they are engaged. Thus, for example, operational management mainly needs technical knowledge and knowledge about people. As we climb to the top, the mentioned is less needed, while conceptual knowledge comes to the fore. It is similar with the skills that employees need to master at different levels. Since service provider is inseparable from the user in the hotel industry, communication skills are also crucial for successful business and cooperation and should be mastered by all employees of a hotel. On the other hand, as is the case with the communication skills, employees are required to know at least one foreign language. In order to prove that statement, we will use the results of the survey on the labor market, qualification and education needs in tourism and hotel industry conducted by the Employment Agency of Montenegro in 2008.

According to this survey, employees in the hotel industry of Montenegro mostly lack knowledge of foreign languages, communication skills, as well as creativity, which means that employees in this sector do not fulfill the basic conditions required for successful operations. On the other hand, employee computer illiteracy in this area is also worrying. These shortcomings are inexcusable for a country that wants to be a tourism destination (see Chart no. 1). If one component within the category Individual does not work, it will affect the entire category, and therefore, all other variables used to measure the effectiveness of operations, as well as the competitiveness of a hotel product. 
In other words, the staff in the hotel industry of Montenegro does not have necessary knowledge and skills, and therefore reduce the effectiveness and efficiency of Montenegrin hotel industry, as well as competitiveness of destinations in the tourism market. We can conclude that the situation has meliorated since the time of the survey, but the problem of employee competence in the hotel industry comes to the fore. In addition, there is a question of staff motivation in the Montenegrin hotel industry.

If we start from the thesis that the customer is satisfied if the service provider is satisfied, that a satisfied employee is employee by the worker, it can be concluded that employee motivation in a typical service activity, such as the hotel industry, is a factor of business success of a hotel.

In Montenegro, a guest has an opportunity to encounter "dissatisfied" service providers on a daily basis, and thus their inappropriate behavior, which is quite irritating, creates a desire to change the place of residence. The question imposes as to what causes such emotional state. The answer probably lies in motivators (things that encourage an individual to act, or the means by which the conflicting needs can be reconciled, or emphasize a need in the way that it has been awarded priority over other needs). They are the kind of instruments which aim to strengthen the desire for realization, thus achieving satisfaction, and the means by which it can influence human conduct. The most commonly used motivators are: money, job security, assigning interesting tasks, public giving of credits, the possibility of training, advancement opportunities, participation in decision-making, the quality of the working environment, self-affirmation and the like (Cetinski, 2006).

Motivators bring about a new dilemma: whether domestic hoteliers are aware of the importance of employee motivation for the effectiveness and efficiency of operations and, if so, which motivators are used most frequently? Unfortunately, local hoteliers (mostly) strive for profit as a primary objective. The goal is not profit, as it is a means to get to the finish line. The ultimate goal are satisfied employees.

The creators of modern management care about employee motivation in the hotel industry of Montenegro, so it is no surprise that the best business is in hotels owned by the renowned hotel companies which are not headquartered in Montenegro, but in the countries corporate headquarters, which, by all criteria, are far ahead of Montenegro.

The third element of category Individual (chart no.1) states that the company provides necessary support to employees. It can be said that this element is not less im- portant than knowledge and skills, as well as employee motivation. On the contrary, job motivation, and willingness to acquire new knowledge and skills, as well as the achievement of better performance and logical and greater effectiveness of the company, depends on the support an employee receives in the workplace. Employee support by the management is closely connected to the motivators discussed in the previous section.

Employees receive support from the company through various forms of training and development rewards that await them if the performance is satisfactory, the equipment they get to use and fair collaboration with colleagues. It is very important, especially when working in a hotel that employees always have in mind that their efforts are rewarded, that their work is not in vain and that they can further progress and develop their skills and knowledge.

It is also important that each employee is made aware of the objectives of the company they work for, as well as that their suggestions and proposals, if justified, will encounter support. What is particularly stimulating for all employees in a hotel is good communication with associates/colleagues/bosses/managers, which will be discussed afterwards. In this way, an employee feels more valuable, which is encouraging, and motivates them to do their best to achieve more favorable results, which would result in the enhanced efficiency and effectiveness of hotel businesses, higher employee satisfaction, and thus higher customer satisfaction.

In addition to the so-called moral support that employees expect from their company, we include means of work that are given to employees, as well as all types of training, development and education, so as to enhance the overall employee performances (Mathis \& Jacson, 2008).

Education and training play a very important role in development of human resources which are at disposal of the hotel industry of Montenegro. Training of personnel in the hotel industry includes two levels, high school and university. Secondary vocational schools for different employee profiles the hotel industry are mostly being established in urban centers or centers of the tourism region, which generates the staff trained for specific jobs of lower level of complexity, such as waiters, maids etc. (Mathis \& Jacson, 2008). Upon graduating from vocational schools, most of them opt for some faculties. In recent years, there has been a large number of accredited programs for tourism and hotel management, but these are mainly academic programs, not applied. Many expect managerial positions after graduation despite lacking any prior experience. While some higher 
education institutions have tried to offer applied studies in tourism and hotel industry, there has been non interest in enrollment. On the other hand, experience and the labor market show that they need highly competent staff in the operational and intermediate levels of the organization. So, the key is to educate and influence population concerning the needs for trained and creative staff in the hotel industry. It is necessary to replace the awareness on "second-class jobs," as is often thought about working in the hotel industry, with the awareness that modern hotel industry requires knowledgeable and creative staff, with all necessary competencies and expertise.

\section{PROPOSED MODEL}

Based on the above-mentioned, we can state that the success of a hotel, quality of a hotel product and its competitiveness depend on guest satisfaction, while guest satisfaction heavily relies on employee satisfaction. Therefore, it is possible to conclude that the success of the hotel, quality of a hotel product and its competitiveness depend on employee satisfaction. Employee satisfaction depends on employee motivation, knowledge and skills, working conditions, working climate, support one receives from the company, teamwork, and good communication between employees etc. All of the specified depends on management. Accordingly, we can adapt the model proposed by Mathis and Jacson and add one category. The amended Model of individual/organizational performance is illustrated below:
Namely, the modified model of individual/organizational performance points to necessity of engagement of human resource management which should constantly monitor employee satisfaction, and support all elements motivating the individual and ensuring better performance, business efficiency and competitive position in the market.

\section{CONCLUSION}

In order to ensure a higher level of effectiveness and efficiency of the hospitality industry, and to increase the competitiveness of Montenegro as a tourism destination on the global tourism market, it is essential that the hotel staff possesses necessary knowledge and skills. As regards the improvement of the existing employee structure in tourism industry, the Human Resources Development Strategy in the Tourism Sector in Montenegro (Ministarstvo turizma i zaštite životne sredine, 2007) highlights the main recommendations for achieving that goal. It would be necessary to improve institutional, organizational and regulatory environment, develop better educational facilities and improve qualification service providers, develop the qualification offers in compliance with the market needs and demands, and to improve the institutions for educating future teachers and managers ("Capacity Development"). Those recommendations should be the basis for priority spheres of activity, both for formal and informal education, but could the important guidelines for the hotel management as well, since the hotel as an organization should

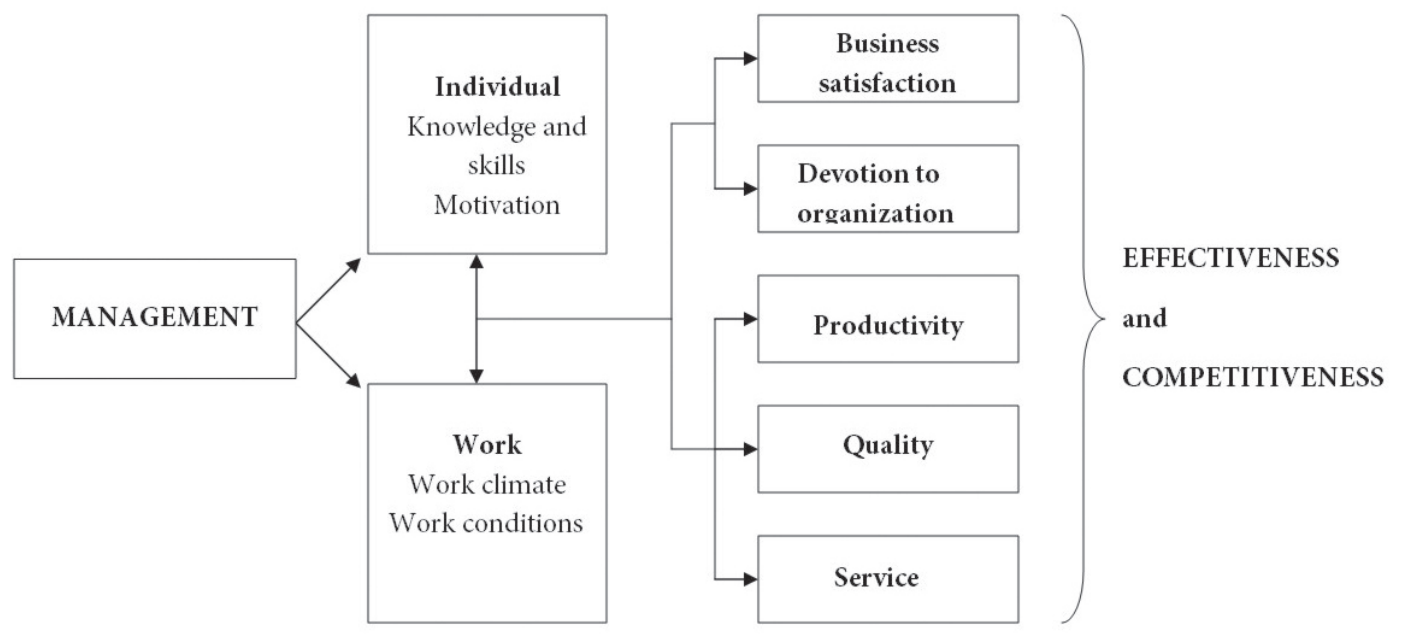

Chart 2. Model of individual/organizational performance

Source: Adapted according to Mathis and Jacson (2008, p. 81). 
also provide its employees with different kinds of trainings and specializations. On the other hand, employee motivation in service sector has a very important role in their engagement and commitment within the organization.

Based on the study conducted, we conclude that for the sake of effective and efficient business, it is necessary to manage human resources in each organization, especially in hotel enterprises. However, this does not mean that they are not managed properly now, but it primarily refers to quality human resources management, i.e. existence of responsible management. Responsible management is quite familiar with all aspects of the production in a hotel, and therefore, the importance of human capital for achieving a competitive advantage in the market.

Quality management of hotel organizations in Montenegro is often lacking, not to speak of human resource management. Based on the above-stated, it can be concluded that the main reason of employee dissatisfaction in the hotel industry in Montenegro is poor management, especially lack of management or inadequate management of human resources. Certainly, there are some companies in Montenegro that are a bright example in this respect. Owing to high-quality education institutions, new generations prefer the hotel industry as an area to express their creativity, make contribution, build a successful career and bring down all the job prejudices in the hotel industry.

\section{REFERENCES}

Avelini, H.I. (1998). Kontroling: upravljanje poslovnim rezultatom. Opatija: Fakultet za turizam i hotelijerstvo.

Bakić, O. (2002). Marketing menadžment turističke destinacije. Beograd: Ekonomski fakultet.

Becker, G.S. (1993). Human Capital: A Theoretical and Empirical Analysis with Special Reference to Education. Chicago: University of Chicago Press.

Čačić, K. (2010). Poslovanje hotelskih preduzeća. Beograd: Univerzitet Singidunum.
Cetinski, V. (2006). Projektni menadžment. Opatija: Fakultet za turizam i hotelijerstvo.

Ćuruvija, I. (2007). Kvalitet usluga turističkih vodiča. Beograd: Zadužbina Andrejević.

DEG, GTZ, CREATOP (2008). Strategija razvoja turizma u Crnoj Gori do 2020. godine. Podgorica: Ministarstvo turizma i zaštite životne sredine.

Kotler, Ph., Bowen, J., \& Makens, J. (2014). Marketing for hospitality and tourism. Upper Saddle River, NJ: Prentice Hall Inc.

Mankju, G. (2006). Principi mikroekonomije. Beograd: Publikum.

Marchante, A.J., \& Ortega, B. (2012). Human Capital and Labour Productivity: A Study for the Hotel Industry. Cornell Hospitality Quarterly, 53(1), 20-30. doi:10.1177/1938965511427698

Mathis, R., \& Jacson, J. (2008). Human resource management. USA: Thomson South-Western.

McFadyen, M.A., \& Cannella, A.A. (2004). Social capital and knowledge creation: Diminishing returns of the number and strength of exchange relationships. Academy of Management Journal, 47(5), 735-746.

Ministarstvo tuizma i zaštite životne sredine Crne Gore (2007). Strategija razvoja ljudskih resursa u sektoru turizma u Crnoj Gori / The Human Resources Development Strategy in the Tourism Sector in Montenegro. Podgorica: The Government Printing Office.

Payne, G.T., Moore, C.B., Griffis, S.E., \& Autry, C.W. (2011). Multilevel Challenges and Opportunities in Social Capital Research. Journal of Management, 37(2), 491-520. doi:10.1177/0149206310372413

Podolny, J.M., \& Baron, J.N. (1997). Resources and relationships: social networks and mobility in the workplace. American Sociological Review, 62(5), 673-693.

Sheldon, P. J., \& Gee, C.Y. (1987). Training needs assessment in the travel industry. Annals of Tourism Research, 14(2), 173-182. doi:10.1016/0160-7383(87)90083-1

Stewart, T.A. (2010). Intellectual Capital: The New Wealth of Organizations. New York: Crown Publishing Group.

Zavod za zapošljavanje Crne Gore (2008). Analiza deficitarnih zanimanja u Crnoj Gori. Podgorica: Zavod za zapošljavanje Crne Gore. 